\title{
ФОРМУВАННЯ ТЕРМІНОЛОГІЧНОЇ КОМПЕТЕНЦІЇ ЗДОБУВАЧІВ ВИЩОЇ ОСВІТИ СПЕЦІАЛЬНОСТІ «МЕНЕДЖМЕНТ»
}

У пропонованій статті автор розглядає проблему вироблення термінологічної компетенції здобувачів вищої освіти спеціальності «Менеджмент» як невід'ємного складника культури їхнього професійного мовлення на заняттях з української мови за професійним спрямуванням і доходить висновку, що формування термінологічної компетенції високого рівня забезпечить раціональна система методів навчання, скерованих на поетапне опанування фахової термінології, яке уможливить оволодіння термінологічним словником і його постійне якісне поповнення й сприятиме виробленню уміння працювати з термінологічною лексикою й навичок правильного терміновживання в спеціальних текстах.

Ключові слова: культура професійного мовлення, термінологічна компетенція, фахова термінологія, терміновживання, спеціальний текст.

Chornovol-Tkachenko R.I. Terminological Competence Forming of Graduate Students Studying Management. Terminological competence is an integral component of speech culture of any professional. It presupposes the corresponding terminology basis and skills of using it efficiently. The issue of researching and learning terminological lexis, and thus, the issue of building up terminological competence of future experts in any field have frequently drawn scholars' attention. At the same time, despite numerous works in the above domain, there are certain gaps in studying the problem considered, which is obvious, taking into account the insufficient quality of the system of activities directed at forming the culture of professional communication, whose part and parcel is terminological competence of future professionals in any field, including future managers.

The aim of this work is to analyze opportunities of forming terminological competence while teaching graduate students (majoring in management) the Ukrainian language. To realize the above mentioned aim, it is necessary to reveal the essence and the structure of the concept «terminological competence», as well as to explicate main approaches, methods and steps of forming it.

The author of the article analytically sums up material from scientific works of the recent years and offers a vision of terminological competence as a conscious motivated usage of terms in their specific meanings that are fixed in the corresponding terminological dictionaries, applying terms with an emphasis on understanding historical processes in lexis and semantics in general and the development systems of terms, in particular, making terms function from the point of view of lexico-semantic relationships in this field, taking into consideration word valence in terms of patterns «a term - a term», «a term - a common word»; consciously following grammar norms of modern standard Ukrainian while using terminological lexical units; relevantly operating terminological lexical units as scientific style entities in the process of creating scientific texts.

The author concludes that forming a high level terminological competence can be ensured only by means of developing a rational system of teaching methods, aimed at step-by-step consistent mastering major terminology that will enable a multi-facet comprehension of terminological vocabularies and their constant high-quality enrichment, enhancing the process of building up skills of working with terminological lexis and of using terms in major-oriented texts in the appropriate way.

Key words: culture of professional communication, terminological competence, major terminology, terminology usage, major-oriented text.

\section{Вступ}

Культура мовлення як «володіння нормами літературної мови у вимові, уживанні слів і їх форм, у побудові речень і вмінні користуватися мовними засобами в певних ситуаціях спілкування» (Дорошенко, 2002: 8) є важливим 
складником професійної компетентності представника будь-якого фаху. Невід'ємним компонентом культури мовлення фахівця тієї чи тієї галузі виступає термінологічна компетенція, що передбачає наявність відповідної термінологічної бази знань й уміння ефективно іiі використовувати. До проблеми вивчення і засвоєння термінологічної лексики, а відтак і до проблеми формування термінологічної компетенції майбутніх спеціалістів того чи того галузевого напряму неодноразово зверталися такі дослідники, як Г. Бондаренко (Бондаренко, 2008), Л. Вікторова (Вікторова, 2009), Н. Глушкова (Глушкова \& Катаржи, 2017), О. Гриджук (Гриджук, 2014), І. Гуменюк (Гуменюк, 2014), Т. Денищич (Денищич, 2012), С. Дорошенко (Дорошенко, 2002), К. Климова (Климова, 2010), Г. Ракшанова (Ракшанова \& Дядюра, 2013), Т. Симоненко (Симоненко, 2006), Т. Стасюк (Стасюк, 2014), Н. Тоцька (Тоцька, 2003), Я. Януш (Януш, 2001) та ін. Незважаючи на значну кількість праць в окресленій царині, у дослідженні зазначеної проблеми є певні прогалини, що виражається в недостатній розробленості системи роботи 3 формування культури професійного мовлення, органічним компонентом якого є термінологічна компетенція майбутніх фахівців певної сфери діяльності, зокрема й майбутніх менеджерів.

Мета статті - проаналізувати можливості формування термінологічної компетенції під час викладання української мови за професійним спрямуванням здобувачам вищої освіти спеціальності «Менеджмент». Для досягнення окресленої мети необхідно з'ясувати сутність і структуру поняття «термінологічна компетенція», а також визначити основні прийоми, методи і засоби іiі формування.

\section{Методи та методики дослідження}

Мета і завдання дослідження зумовили застосування таких теоретичних методів, як аналіз (вивчення наукової літератури з метою з'ясування стану розробленості розглядуваної проблеми), зіставлення (порівняння різних поглядів на досліджувану проблему для визначення напрямів дослідження і поняттєво-категорійного апарату), синтез, узагальнення, моделювання (для розроблення методики формування термінологічної компетенції майбутніх менеджерів).

\section{Результати та дискусії}

Термінологічну компетенцію, що є базовою в подальшій професійній і науковій діяльності будь-якого фахівця, дослідники розглядають порізному. Так, Т. Симоненко визначає їі як «інтегральну характеристику ділових і особистісних якостей людини, що відображає не тільки рівень знань, умінь і навичок, достатніх для досягнення цілей професійної діяльності, але й високу соціально-моральну позицію професіонала» (Симоненко, 2006: 131). Г. Онуфрієнко наголошує, що термінологічна компетенція - це поглиблені загальномовні знання та скориговані й професійно скеровані мовленнєві вміння і навички, екстрапольовані на мову фаху (Онуфрієнко, 2006: 17). Т. Денищич потрактовує це поняття як здатність фахівця вільно сприймати й породжувати професійні тексти в усному і писемному мовленні з використанням фахової лексики, що грунтується на власній внутрішній мотивації та 
досвіді, ураховуючи лінгвістичні та соціальні правила (Денищич, 2012). Незважаючи на певні відмінності в наведених дефініціях, у них визначається наскрізний акцент: наявність відповідного рівня знань наукової термінології з фаху, а також умінь і навичок доцільного ії використання, необхідних для досягнення належного рівня культури фахового мовлення, а відтак i професійної компетентності.

Термінологічна компетенція як складник культури професійного мовлення, а отже, і загальної професійної компетентності, поєднує у своїй структурі термінологічну культуру й термінологічну грамотність. Термінологічну культуру вчені пропонують розглядати як комплекс мовних і мовленнєвих знань, умінь і навичок фахівця, за допомогою яких формується фундамент теорії і практики фаху, необхідних для глибшого осмислення й засвоєння його поняттєвої і категорійної бази, для реалізації різних актів дослідницького, творчо-аналітичного і практичного характеру, що формують здатність фахівця-мовця до самостійного термінотворення і терміновпорядкування (Огар, 2009). Дослідники відзначають, що термінологічна культура формується на основі нерозривного поєднання глибокого знання фаху зі знанням мовних норм, законів і механізмів функціонування як логіко-поняттєвої, так і лексичної підсистем терміносистеми, тобто на синтезі фахової ерудиції з мовознавчою, зокрема термінознавчою (Огар, 2009).

Термінологічна ж грамотність допомагає фахівцеві «уникати сліпого калькування під час перекладу фахової літератури та створення текстів професійного спрямування, орієнтує на вживання нормативних форм термінолексем та фахових фразеологічних терміносполучень» (Стасюк, 2014: 157).

Із огляду на викладене термінологічну компетенцію потрактовуємо як свідоме умотивоване вживання термінів у властивому для них значенні, закріпленому у відповідних термінологічних словниках, використання термінів з урахуванням історичних процесів у лексиці й семантиці в цілому й розвитку терміносистеми зокрема, уживання термінів з огляду на лексикосемантичні відношення між ними, урахування валентності слів у площині термін - термін, термін - загальновживане слово; усвідомлене дотримання граматичних норм сучасної української літературної мови під час уживання термінологічної лексики; доречне оперування термінолексемами як одиницями наукового стилю під час складання наукових текстів.

Для вироблення навичок термінологічної грамотності й формування термінологічної культури здобувачів вищої освіти доцільно застосовувати в навчальному процесі завдання різних типів.

Так, методично виправданим буде виконання завдань, спрямованих на вироблення навичок розрізнення термінів і номенклатурних назв, термінологічної лексики і професіоналізмів, визначення характеристик термінолексем за їх належністю до галузі, за походженням, лексико-семантичними, морфологічними, структурними і словотвірними ознаками, уміння вживати правильну терміноодиницю, якщо вона має кілька значень або належить до відповідного синонімічного ряду чи паронімічної пари. Наведемо орієнтовні зразки таких завдань: 
1. Згрупуйте подані слова і словосполучення за їхньої належністю до групи термінів, групи номенклатурних назв і професіоналізмів.

(Показник якості, грошовий голод, собівартість, чорна каса, базова нормативна собівартість, ділити диню, показник, портфель інновацій, реімпорт, податковий рай).

2. 3'ясуйте значення поданих слів (за необхідності звертайтеся до тлумачного словника). Схарактеризуйте наведені терміни за їхньою належністю до загальнонаукових чи вузькоспеціальних.

(Система, інжиніринг, закон, рентабельність, структура, тендер, еквівалент, форфейтинг).

3. Згрупуйте запропоновані термінологічні одиниці за походженням: запозичені, власне українські, гібридні (комбіновані).

(Функціонування, вартість, акція, цільова програма, готівка, емісія, рахунок, хедж, амортизована вартість).

4. Скориставшись словником, поясніть значення багатозначних термінів. Із кожним із них складіть (або випишіть зі спеціальної літератури) речення, яке б ілюструвало зафіксоване вами значення.

(Алгоритм, гіпотеза, декларація, кліринг).

5. 3'ясуйте значення поданих термінів (за необхідності звертайтеся до тлумачного словника). Із кожним із них складіть словосполучення, які б ілюстрували ваше пояснення виявлених лексичних значень.

(Лаг - лаж, емітент - ремітент, інжиніринг - реінжиніринг, варант варіант).

6. До поданих термінологічних одиниць доберіть синоніми.

( Ідеальна нормативна собівартість, рентабельність капіталу, операційний бюджет, внутрішня норма прибутку).

Формування навичок створення власних текстів фахового наповнення чи перекладу таких текстів неможливе без виконання вправ, які сприятимуть засвоєнню знань щодо особливостей сполучуваності термінологічних одиниць між собою, а також із загальновживаними словами. Для вироблення такого уміння доречно застосовувати завдання на добір пари або вибір потрібного слова з-поміж запропонованих, як-от:

1. До поданих іменників доберіть прикметники, наведені в довідці. Запишіть утворені термінологічні словосполучення у тій граматичній формі, у якій вони вживаються в науковій літературі.

(Комунікація, план, ефективність, підхід, метод).

Довідка: композиційний, вертикальна, організаційний, статистичний, довготерміновий.

2. Запишіть термінологічні словосполучення, добираючи потрібні слова $з$ дужок.

(Схема організаційної (структури, будови) (управління, керування), школа людських (взаємин, відносин, взаємовідносин, стосунків), визначення (чисельності, численності, множинності) працівників).

3. Виправте помилки в наведених словополученнях.

(Потенціальний покупець, печатні інформативні каталоги, конфлікт інтересів відсутній, представлений у якості висококваліфікованого управліния, 
фірма знаходиться у скрутному положенні, невідкладне вирішення проблеми, вирішення управлінської задачі).

Із метою вироблення навичок правильного вживання термінів як граматичних одиниць доцільно удаватися до завдань такого типу:

1. Згрупуйте наведені іменники чоловічого роду за семантичною належністю й запишіть їх у формі родового відмінка однини.

(Долар, менеджер, консалтинг, гонорар, журнал, координатор, документообіг, бенч-маркінг, облік, звіт, аудит, споживач, тренінг, постачальник, аналіз, ресепшионіст, мерчандайзинг, хедхантер, договір, статут, менеджмент).

2. Виправте помилки в наведених словосполученнях. Запишіть нормативний варіант.

(Семінар по проблемам продажі, самі низькі ціни, у відповідності з вимогами, у значній мірі залежить, розраховується в залежності від, затрати по доставці, визначити по формулі, розповідали за практику, цей проект більш дорожчий попереднього).

Уважаємо, що запропоновані зразки практичних завдань з української мови сприятимуть формуванню термінологічної компетенції здобувачів вищої освіти.

Рівень сформованості термінологічної компетенції майбутніх менеджерів доцільно оцінювати за пізнавальним (обсяг знань фахової термінології, якість знань фахової термінології, розуміння сутності та особливостей фахової термінології; здатність до синтезу, аналізу, узагальнення та структурування професійної термінології), мотиваційним (наявність пізнавального інтересу до фахової термінології, наявність внутрішніх мотивів засвоєння термінологічної лексики і бажання підвищити культурний та інтелектуальний рівень) і діяльнісним (сформованість практичних умінь уживання фахових термінів в усному й писемному мовленні, практична діяльність, спрямована на укладання фахових словників, виявлення комунікативномовленнєвої творчої активності) критеріями (Вікторова, 2009: 9-10).

\section{Висновки}

Викладене дозволяє стверджувати, що раціональна система методів навчання, скерованих на поетапне опанування фахової термінології, забезпечить оволодіння термінологічним словником і його постійне якісне поповнення, сприятиме виробленню уміння працювати з термінологічною лексикою й навичок правильного терміновживання в спеціальних текстах, а отже, уможливить формування термінологічної компетенції високого рівня.

Продовження розпочатого дослідження вбачаємо у створенні цілісної системи формування термінологічної компетенції здобувачів вищої освіти спеціальності «Менеджмент» на заняттях з української мови за професійним спрямуванням.

\section{ЛІТЕРАТУРА}

1. Бондаренко Г. П. Методика навчання економічних спеціальностей української наукової термінології в умовах східного регіону України: автореф. дис. ... канд. пед. наук: спец. 13.00.02 «Теорія і методика навчання української мови». Київ, 2008. 21 с. 
2. Вікторова Л. В. Формування професійно-термінологічної компетентності студентів вищих аграрних навчальних закладів у фаховій підготовці: автореф. дис. ... канд. пед. наук: спец. 13.00.04 «Теорія і методика професійної освіти». Чернігів, 2009. 23 с. 3. Гриджук О. С. Актуальність курсу «Фахова термінологія» у вищій школі нефілологічного профілю. Наукові записки Національного університету «Острозька академія». Серія: Психологія і педагогіка. 2014. Вип. 30. С. 50-54. 4. Гуменюк I. Формування термінологічної компетенції студентів у контексті викладання дисципліни «Українська мова (за професійним спрямуванням)». Освітній простір України. 2014. Вип. 2. С. 38-42. 5. Денищич Т. А. Роль термінологічної компетентності у становленні майбутнього фахівця [Електронний ресурс]. Режим доступу: URL: virtkafedra.ucoz.ua /el_ gurnal/pages/.../Denyshich_t. pdf. 6. Дорошенко C. I. Основи культури і техніки усного мовлення. Харків: ХДПУ ім. Г. С. Сковороди, 2002. 144 с. 7. Климова К. Я. Теорія і практика формування мовнокомунікативної професійної компетенції студентів нефілологічних спеціальностей педагогічних університетів. Житомир: Рута, 2010. 560 с. 8. Огар Е. І. Українська видавнича термінологія: нормалізаційні та функціональні аспекти. Українське журналістикознавство. 2009. № 10. С. 31-35. 9. Онуфрієнко Г. Науковий стиль української мови. Київ: Центр навчальної літератури, 2006. 312 с. 10. Проблеми вивчення фахової термінології на заняттях з дисципліни «Українська мова (за професійним спрямуванням)» / А. О. Троян, Н. М. Глушкова, Н. І. Кантаржи, М. І. Мирошниченко. Південь Украӥни: етноісторичний, мовний, культурний та релігійний виміри: збірник наукових праць. 2017. Вип. 6. С. 365-370. 11. Ракшанова Г. Ф., Дядюра Г. М. Вивчення фахової термінології як елемент розвитку творчих здібностей у студентів технічного профілю на заняттях з української мови. Актуальні проблеми філології. Матеріали міжнародної науково-практичної конференції. Херсон: Гельветика, 2013. С. 15-18. 12. Симоненко Т. В. Теорія і практика формування професійної мовнокомунікативної компетенції студентів філологічних факультетів. Черкаси: Вид. Вовчук О. Ю., 2006. 328 с. 13. Стасюк Т. В. Мовно-професійна компетентність / термінологічна компетентність у розрізі соціолінгвістики. Дослідження з лексикологї̈ $і$ граматики української мови. 2014. Вип. 15. С. 153-161. 14. Тоцька Н. Методика роботи викладачів вищого технічного навчального закладу над українським професійним мовленням студентів. Дивослово. 2003. № 1. С. 62-65. 15. Януш Я. Роль термінології у формуванні мовно-професійної компетентності фахівців економічного профілю. Українська термінологія і сучасність. Київ: КНЕУ, 2001. Вип.4. С. 15-19.

\section{REFERENCES}

1. Bondarenko, G. P. (2008). Metodyka navchannia ekonomichnykh spetsialnostei ukrainskoi naukovoi terminolohii $\mathrm{v}$ umovakh skhidnoho rehionu [Methodology of teaching economic specialties of Ukrainian scientific terminology in the conditions of the eastern region of Ukraine]. Extended abstract of candidate's thesis. Kyiv [in Ukrainian]. 2. Viktorova, L. V. (2009). Formuvannia profesiino-terminolohichnoi kompetentnosti studentiv vyshchykh ahrarnykh navchalnykh zakladiv $u$ fakhovii pidhotovtsi [Formation of vocational and terminological competence of students of higher agricultural educational institutions in professional training]. Extended abstract of candidate's thesis. Chernigiv [in Ukrainian]. 3. Grydzhuk, O. Ye. (2014). Aktualnist kursu "Fakhova terminolohiia" u vyshchii shkoli nefilolohichnoho profiliu [Actuality of the course "Professional terminology" in the high school of non-philological profile]. Naukovi zapysky Natsionalnoho universytetu "Ostrozka akademiia”. Seriia: Psykholokhiia I pedahohika - Scientific notes of the National University “Ostroh Academy”. Ser.: Psychology and pedagogy (issue 30), (pp. 50-54) [in Ukrainian]. 4. Gumeniuk, I. (2014). Formuvannia terminolohichnoi kompetentsii studentiv u konteksti vykladannia dystsypliny "Ukrainska mova (za profesiinym spriamuvanniam)" [Formation of terminological competence of students in the context of teaching the discipline "Ukrainian language (in professional orientation)"]. Osvitnii prostir Ukrainy - Educational space of Ukraine (issue 2), (pp. 38-42) [in Ukrainian]. 5. Denyshchych, T. A. (2012). Rol terminolohichnoi 
kompetentnosti u stanovlenni maibutnoho fakhivtsia [The role of terminological competence in the formation of a future specialist]. Retrieved from virtkafedra.ucoz.ua /el_gurnal/page s/.../Denyshich_t. pdf [in Ukrainian]. 6. Doroshenko, S. I. (2002). Osnovy kultury i tekhniky usnoho movlennia [Fundamentals of culture and techniques of oral speech]. Kharkiv: KhSPU [in Ukrainian]. 7. Klymova, K. Ya. (2010). Teoriia i praktyka formuvannia movnokomunikatyvnoi profesiinoi kompetentnosti studentiv nefilolohichnoho spetsialnostei pedahohichnykh universytetiv [Theory and practice of formation of language communicative professional competence of students of non-philological specialties of pedagogical universities]. Zhytomyr: Ruta [in Ukrainian]. 8. Ogar, Ye. I. (2009). Ukrainska vydavnycha terminolohiia: normalizatsiini ta funktsionalni aspekty [Ukrainian Publishing Terminology: Normalizing and Functional Aspects]. Ukrainske zhurnalistykoznavstvo - Ukrainian journalism, 10, 31-35 [in Ukrainian]. 9. Onufriienko, G. (2006). Naukovyi styl ukrainskoi movy [Scientific style of the Ukrainian language]. Kyiv: Tsentr navchalnoi literatury [in Ukrainian]. 10. Problemy vyvchennia fakhovoi terminolohii na zaniattiakh z dystsypliny "Ukrainsra mova (za profesiinym spriamuvanniam)" [Problems of studying of professional terminology in classes on discipline "Ukrainian language (in professional orientation)"]. (4 $4^{\text {th }}$ ed.). Pivden Ukrainy: etnoistorychnyi, movnyi, kulturnyi ta relihiinyi vymiry - South of Ukraine: ethno-historical, linguistic, cultural and religious dimensions (issue 6), (pp. 365-370) [in Ukrainian]. 11. Rakshanova, G. F. \& Diadiura G. M. (2013). Vyvchennia fakhovoi terminolohii yak element rozvytku tvorchykh zdibnostei u studentiv tekhnichnoho profiliu na zaniattiakh z ukrainskoi movy [Study of professional terminology as an element of the development of creative abilities of technical students in Ukrainian language lessons]. Aktualni problem filolohii: Materialy mizhnarodnoi naukovopraktychnoi konferentsii - International scientific and practical conference. Kherson: Helvetyka [in Ukrainian]. 12. Symonenko, T. V. (2006). Teoriia i praktyka formuvannia profesiinoi movnokomunikatyvnoi kompetentsii studentiv filolohichnykh fakultetiv [Theory and practice of formation of professional language communicative competence of students of philological faculties]. Cherkasy [in Ukrainian]. 13. Stasiuk, T. V. (2014). Movno-profesiina kompetentnist / terminolohichna kompetentnist u rozrizi sotsiolinhvistyky [Linguistic-professional competence / terminological competence in the context of sociolinguistics]. Doslidzhennia z leksykolohii $i$ hramatyky ukrainskoi movy - Studies in lexicology and grammar of the Ukrainian language (issue 15), (pp. 153-161) [in Ukrainian]. 14. Totska, N. (2003). Metodyka roboty vykladachiv vyshchoho tekhnichnoho navchalnoho zakladu nad ukrainskym profesiinym movlenniam studentiv [Methodology of the work of teachers of higher technical educational institutions over Ukrainian professional broadcasting of students]. Dyvoslovo - Miracleword, 1, 62-65 [in Ukrainian]. 15. Yanush, Ya. (2001). Rol terminolohii u formuvanni movno-profesiinoi kompetentnosti fakhivtsiv ekonomichnoho profiliu [The role of terminology in forming the language and professional competence of specialists in the economic field]. Ukrainska terminolohiia i suchasnist - Ukrainian terminology and modernity (issue 4), (pp. 15-19). Kyiv: KNEU [in Ukrainian].

Черновол-Ткаченко Раӥса Іванівна - кандидат педагогічних наук, професор, професор кафедри наукових основ управління і психології, директор Інституту підвищення кваліфікації, перепідготовки, Харківський національний педагогічний університет імені Г. С. Сковороди; вул. Валентинівська, 2, м. Харків, 61168, Україна.

Tel.: +38 (057) 68-02-92

E-mail:ipo1975@ukr.net

https://orcid.org/0000-0002-6292-6170

Chernovol-Tkachenko Raisa Ivanivna - PhD in Philology, Professor, Department of Scientific Basics of Management and Psychology, Director of the Institute of Further Training, Retraining, H. S. Skovoroda Kharkiv National Pedagogical University; Valentynivska Str., 2, Kharkiv, 61168, Ukraine. 